\title{
Meningkatkan Hasil Belajar Ekonomi/Akuntansi Siswa Melalui Pembelajaran Kooperatif Tipe Think Pair Share di SMA Negeri 2 Aikmel
}

\author{
Baiq Evi Aprian Sutanti \\ SMA Negeri 2 Aikmel, Kabupaten Lombok Timur NTB \\ Corresponding Author. Email: Evisutanti78@gmail.com
}

\begin{abstract}
This study aims to improve the learning outcomes of economic / accounting students using cooperative learning type Think Pair Share at SMA Negeri 2 Aikmel. The research method used is classroom action research which is carried out in two cycles where each cycle consists of four stages of activity, namely (1) action planning, (2) action implementation, (3) action observation, and (4) action reflection. The research subjects were 27 students of class XII IPS at SMA Negeri 2 Aikmel. Data collection techniques include observation, tests, documentation, and interviews. While the data analysis technique used qualitative and quantitative descriptive analysis. The results showed that the economic/accounting learning outcomes of students in class XII IPS experienced an increase through cooperative learning type TPS at SMA Negeri 2 Aikmel with several indicators including an increase in student activism by $14 \%$, an increase in student activeness in participating in cooperative learning type TPS as much as 16\%, an increase in student activity in pair / group discussions by $20 \%$, an increase in learning completeness by $15 \%$, and an increase in student activeness in discussions that is greater than other indicators such as activeness and completeness of student learning outcomes.
\end{abstract}

\begin{abstract}
Abstrak: Penelitian ini bertujuan untuk meningkatkan hasil belajar ekonomi/ akuntansi siswa menggunakan pembelajaran kooperatip tipe Think Pair Share di SMA Negeri 2 Aikmel. Metode penelitian yang digunakan adalah penelitian tindakan kelas yang dilaksanakan dalam dua siklus di mana masing-masing siklus terdiri dari empat tahapan kegiatan, yaitu (1) perencanaan tindakan, (2) pelaksanaan tindakan, (3) observasi tindakan, dan (4) refleksi tindakan. Subjek penelitian ini adalah siswa kelas XII IPS SMA Negeri 2 Aikmel sebanyak 27 siswa. Teknik pengumpulan data meliputi observasi, tes, dokumentasi, dan wawancara. Sedangkan teknik analisis datanya menggunakan analisis deskriptif kualitatif dan kuantitatif. Hasil penelitian menunjukkan bahwa hasil belajar ekonomi/akuntansi siswa kelas XII IPS mengalami peningkatan melalui pembelajaran kooperatif tipe TPS di SMA Negeri 2 Aikmel dengan beberapa indikator diantaranya peningkatan keaktifan siswa dalam apersepsi sebanyak $14 \%$, peningkatan keaktifan siswa dalam mengikuti pembelajaran kooperatif tipe TPS sebanyak $16 \%$, peningkatan keaktifan siswa dalam diskusi berpasangan/kelompok sebanyak $20 \%$, peningkatan ketuntasan hasil belajar sebesar $15 \%$, dan peningkatan keaktifan siswa dalam diskusi yang lebih besar dibandingkan dengan indikator lainnya seperti keaktifan dan ketuntasan hasil belajar siswa.
\end{abstract}

How to Cite: Sutanti, B. (2021). Meningkatkan Hasil Belajar Ekonomi/Akuntansi Siswa Melalui Pembelajaran Kooperatif Tipe Think Pair Share (TPS) di SMA Negeri 2 Aikmel. Jurnal Paedagogy, 8(1). doi:https://doi.org/10.33394/jp.v8i1.3236

\section{Pendahuluan}

Pendidikan berperan penting dalam rangka menghadapi tuntutan zaman yang semakin kompleks dan kompetitif di hampir semua aspek kehidupan. Menurut Heryati dan Muhsin (2014), pendidikan secara langsung ataupun tidak langsung berimplikasi positif terhadap kelangsungan hidupo suatu bangsa dalam percaturan bangsa di dunia. Pendidikan seperti 
yang ditegaskan dalam UU Sisdiknas No. 20 Tahun 2003 adalah usaha sadar dan terencana untuk mewujudkan suasana belajar dan proses pembelajaran agar peserta didik secara aktif mengembangkan potensi dirinya untuk memiliki kekuatan spiritual keagamaan, pengendalian diri, kepribadian, kecerdasan, akhlak mulia, serta keterampilan yang diperlukan dirinya dan masyarakat. Dalam undang-undang ini tersirat amanat yang sangat luhur agar baik para pendidik maupun unsur-unsur lainnya secara bersama-sama berupaya untuk meningkatkan kualitas peserta didik sehingga mereka menjadi orang-orang yang cerdas, berkepribadian dan beradab serta beguna bagi masyarakat.

Pendidikan merupakan suatu usaha untuk mencapai tujuan pendidikan. Adapun tujuan pendidikan di negara kita seperti tertuang dalam dalam Undang-Undang Sisdiknas adalah mencerdaskan kehidupan bangsa dan mengembangkan manusia seutuhnya yaitu manusia yang beriman dan bertakwa terhadap Tuhan Yang maha Esa dan berbudi pekerti luhur, memiliki pengetahuan dan keterampilan, sehat jasmani dan rohani, berkepribadian yang mantap dan mandiri serta bertanggung jawab kemasyarakatan dan kebangsaan. Selanjutnya, Idi (2014) menyatakan bahwa jika, pembangunan nasional bertujuan untuk menciptakan pembangunan manusia Indonesia yang berilmu pengetahuan berteknologi dan beriman bertaqwa, pendidikan nasional tentunya harus berupaya untuk menuju ke arah pembangunan tersebut. Dengan demikian, pendidikan dapat diharapkan untuk mengembangkan wawasan peserta didik terhadap ideologi, politik, sosial, ekonomi dan budaya secara tepat dan benar sehingga membawa kemajuan pada individu dan masyarakat dan negara untuk mencapai tujuan pembangunan nasional.

Berbagai upaya telah dilakukan untuk meningkatkan kualitas pendidikan di negara kita, salah satunya adalah memperbaiki kualitas pembelajaran di lembaga-lembaga pendidikan kita. Salah satu wujud pelaksanaan pendidikan adalah proses pembelajaran. Menurut Rustaman (2001), proses pembelajaran merupakan proses yang di dalamnya terdapat kegiatan interaksi antara guru-siswa dan komunikasi timbal balik yang berlangsung dalam situasi edukatif untuk mencapai tujuan belajar Dalam proses pembelajaran, guru dan siswa merupakan dua komponen yang tidak bisa dipisahkan. Antara dua komponen tersebut harus terjalin interaksi yang saling menunjang agar hasil belajar siswa dapat tercapai secara optimal. Proses pembelajaran tidak akan berjalan dengan lancar apabila tidak didukung dengan komponen-komponen dalam pembelajaran, karena antara proses pembelajaran dengan komponen pembelajaran saling berkaitan dan membutuhkan. Komponen dalam pembelajaran sangat penting keberadaannya karena dengan pembelajaran diharapkan perilaku siswa akan berubah ke arah yang positif dan diharapkan dengan adanya proses belajar mengajar akan terjadi perubahan tingkah laku pada diri siswa.

Kondisi pembelajaran yang kondusif, aman, dan menyenangkan diharapkan mampu membuat siswa belajar, karena secara tidak langsung siswa akan termotivasi untuk aktif dalam kegiatan belajar mengajar dikelas. Trinova (2012) mengemukakan bahwa dalam konteks pembelajaran menyenangkan, siswa lebih diarahkan untuk memiliki motivasi tinggi dalam belajar dengan menciptakan situasi yang menyenangkan dan mengembirakan. Suasana pembelajaran yang menyenangkan dan berkesan akan menarik minat peserta didik untuk terlibat secara aktif, sehingga tujuan pembelajaran dapat dicapai maksimal.

Kegiatan pembelajaran terdiri atas komponen-komponen yang saling bekerja sama untuk mencapai tujuan pembelajaran. Adapun komponen-komponen tersebut antara lain: (a) peserta didik, (b) tenaga pendidik, (c) materi pelajaran, (d) media atau peralatan pembelajaran, (e) strategi dan metode pembelajaran, (f) evaluasi atau hasil penilaian, (g) lingkungan pembelajaran, dan (h) pengelolaan kelas (Iskandar, 2009). Apabila semua 
komponen tersebut dapat bekerjasama secara maksimal maka kegiatan belajar mengajar akan berjalan lancar dan diharapkan hasil belajar siswa baik dan tujuan pembelajaran tercapai.

Salah satu komponem komponen penting pembelajaran adalah metode pembelajaran. Untuk mencapai tujuan pembelajaran, guru tentunya harus aktif dan cerdas dalam memilih metode pembelajaran yang akan digunakan ketika melaksanakan pembelajaran karena siswa memiliki tingkat kemampuan atau daya serap yang berbeda-beda. Selain itu, metode pembelajaran sangat penting bagi berlangsungnya proses pembelajaran. Siswa tidak akan berhasil dalam belajarnya jika metode pembelajaran yang digunakann kurang tepat dan siswa mungkin kurang tertarik dengan proses pembelajaran yang terjadi. Metode mengajar sebagai strategi dalam mencapai tujuan belajar mengajar harus dipilih dan ditentukan lebih dahulu sebelum diselenggarakan kegiatan belajar mengajar. Menurut Djamarah (2006) suatu cara yang dipergunakan untuk mencapai tujuan yang telah ditetapkan. Dalam kegiatan belajar mengajar, metode diperlukan oleh guru agar penggunaanya bervariasi sesuai yang ingin dicapai setelah pengajaran berakhir. Jadi metode pembelajaran adalah cara atau tahapan yang digunakan dalam interaksi antara peserta didik dan pendidik untuk mencapai tujuan pembelajaran yang telah ditetapkan sesuai dengan materi dan mekanisme metode pembelajaran.

Salah satu masalah utama dalam proses pembelajaran yang kita hadapi adalah hasil belajar siswa yang tercermin dalam sikap, perilaku dan prestasi belajar (nilai) siswa secara umum. Tidak sedikit siswa seringkali melalaikan bahkan bersikap acuh terhadap tugas-tugas yang diberikan kepada mereka seperti tidak mengerjakan PR atau tugas-tugas yang lain, mengacuhkan penjelasan materi dari guru, bahkan masih banyak juga siswa yang kesulitan menghadapi soal ulangan atau ujian semester pada beberapa mata pelajaran sehingga nilai mereka pun tidak maksimal. Biasanya mereka mengalami kesulitan pada mata pelajaran yang membutuhkan pemahaman, ketelitian dan perhitungan. Jadi dapat dikatakan bahwa masih banyak siswa yang memiliki hasil belajar atau nilai yang rendah.

Berdasarkan hasil studi pendahuluan yang telah dilakukan, permasalahan yang dikemukakan di atas juga terjadi pada siswa di Sekolah Menengah Atas (SMA) Jurusan Ilmu Pengetahuan Sosial (IPS) tepatnya siswa di kelas XII IPS 3 SMA Negeri 2 Aikmel yang menganggap bahwa mata pelajaran ekonomi/akuntansi khususnya materi-materi akuntansi sulit dipahami seperti yang diungkapan oleh beberapa siswa yaitu Imam Nur Rahmat, Anita, dan Yusril Ihza Mahendra. Mereka menegaskan bahwa untuk dapat mengerjakan soal-soal akuntansi diperlukan waktu yang lama karena mereka harus memahami, menghitung, mencatat transaksi-transaksi yang ada dengan teliti dan apabila salah dalam mencatat harus mengulang pencatatan dari awal.

Setelah melaksanakan studi pendahuluan dalam bentuk observasi saat kegiatan belajar mengajar (KBM) berlangsung di kelas XII IPS 3 SMA Negeri 2 Aikmel. Dari observasi tersebut didadapatkan fakta bahwa mahasiswa memiliki keaktifan dan motivasi yang rendah dalam belajar akuntansi yang ditunjukkan dalam perilaku mereka ketika mengikuti pembelajaran akuntansi. Fakta lainnya yang didapatkan adalah suasana kelas yang cukup gaduh dengan lelucon yang di buat oleh beberapa siswa sehingga siswa yang lain menjadi ikut tertawa dan tidak konsentrasi dalam mengikuti pelajaran. Selain itu, beberapa siswa tidak secara fokus dan sungguh-sungguh memperhatikan penjelasan dari guru yang sedang menjelaskan pelajaran, bahkan mereka lebih banyak berbicara atau ngobrol dengan temanteman mereka dibandingkan memperhatikan penjelasan dari guru. Tentu saja hal ini membuat siswa tidak dapat menangkap dan memahami materi pelajaran yang disampaikan oleh guru 
secara maksimal. Hal ini dibuktikan dengan beberapa siswa yang masih tampak kebigungan ketika menjawab soal-soal akuntansi yang diberikan kepada mereka.

Berdasarkan nilai ulangan akhir semester pertama akuntansi dengan KKM (Kriteria Ketuntasan Minimum) sebesar 70 diketahui bahwa 58\% siswa telah lulus KKM sedangkan 42\% siswa tidak tuntas. Berdasarkan kondisi yang dipaparkan tersebut dapat disimpulkan bahwa hasil belajar siswa masih rendah. Peneliti juga telah melakukan wawancara beberapa siswa. Beberapa siswa mengungkapkan bahwa kondisi kelas yang tidak kondusif, teman yang suka ramai di dalam kelas, cara guru menyampaikan materi kurang jelas, menjadi alasan siswa untuk malas belajar sehingga hasil belajar mereka rendah. Salah satu alternatif yang dapat ditempuh untuk meningkatkan hasil belajar siswa adalah melalui kreativitas yang dimiliki guru dalam memilih metode mengajar. Selama ini guru sudah menggunakan metode ceramah bervariasi, tetapi masih banyak siswa yang merasa kesulitan dalam memahami konsep akuntansi sehingga perlu dicari suatu model pembelajaran akuntansi yang sesuai dengan kondisi siswa dan kelas tersebut, agar pembelajaran akuntansi dapat membuat siswa tertarik dan termotivasi.Salah satu model pembelajaran yang diyakini mampu meningkatkan keaktifan, motivasi, dan hasil belajar siswa adalah model pembelajaran kooperatif.

Pembelajaran kooperatif adalah strategi pembelajaran di mana siswa belajar bersama dalam kelompok-kelompok kecil dan saling membantu satu sama lain. Dalam menyelesaikan tugasnya, setiap anggota kelompok bekerja sama dan membantu untuk memahami suatu bahan pelajaran. Usman (2002) mendefinisikan pembelajaran kooperatif sebagai belajar kelompok atau bekerjasama. Sedangkan menurut Burton yang dikutip oleh Nasution (2000), pembelajaran kooperatif atau kerjasama ialah cara individu mengadakan relasi dan bekerjasama dengan individu lain untuk mencapai tujuan bersama.

Menurut Slavin (dalam Burengge, 2020; Harni, 2020; Haulid, 2020; Noge, 2020; \& Suryani, 2018), menjelaskan bahwa penelitian tentang pengaruh pembelajaran kooperatif terhadap hasil belajar siswa yakni dari 45 laporan hasil penelitian tersebut 37 diantarannya menunjukkan bahwa kelas kooperatif memperlihatkan hasil belajar yang signifikan dengan kelompok kontrol dan tidak satupun yang menunjukkan bahwa pembelajaran kooperatif berpengaruh negatif terhadap hasil belajar siswa. Jadi, pembelajaran kooperatif merupakan strategi pembelajaran untuk mencapai sukses bersama dalam suatu kelompok kecil, yang beranggotakan para siswa dengan tingkat kemampuan yang berbeda.

Pembelajaran kooperatif dimaksudkan untuk meningkatkan pemahaman terhadap materi pelajaran. Tiap anggota kelompok merespon bukan saja materi pelajaran yang diajarkan tetapi juga membantu belajar anggota tim lainnya agar berkreasi dalam suasana kondusif. Terdapat beberapa tipe pembelajaran kooperatif salah satu di antaranya pembelajaran kooperatif tipe Think Pair Share (TPS). Pembelajaran kooperatif tipe TPS adalah jenis pembelajaran kooperatif di mana siswa belajar berpasangan, sehingga memberi siswa lebih banyak waktu untuk berpikir, merespon, dan saling membantu dalam menyelesaikan suatu permasalahan. Sa'idah (2006) mengatakan bahwa TPS merupakan suatu model pembelajaran kooperatif yang memberi siswa waktu untuk berpikir dan merespon serta saling bantu satu sama lain. Model ini memperkenalkan ide "waktu berpikir atau waktu tunggu" yang menjadi faktor kuat dalam meningkatkan kemampuan siswa dalam merespon pertanyaan. Kemudian Anita Lie (2005) menyebutkan bahwa TPS adalah salah satu tipe pembelajaran kooperatif yang cocok diterapkan untuk semua mata pelajaran dan semua tingkat usia anak. Sehingga TPS juga sesuai apabila diterapkan dalam mata pelajaran ekonomi/akuntansi. 
Mata pelajaran ekonomi/akuntansi pada kompetensi dasar menyusun laporan keuangan perusahaan jasa adalah mata pelajaran yang membutuhkan ketelitian dan kecermatan. Alternatif penggunaan model pembelajaran kooperatif tipe TPS pada pembelajaran akuntansi diharapkan dapat meningkatkan minat, motivasi dan keaktifan siswa, dengan cara menempatkan siswa belajar secara berkelompok sehingga akan lebih mudah menemukan dan memahami konsep- konsep yang sulit apabila mereka dapat saling mendiskusikan dengan temannya. Dan pada akhirnya hasil belajar siswa pun mengalami peningkatan. Adapun tujuan dari penelitian ini adalah untuk meningkatkan hasil belajar akuntansi siswa kelas XII IPS 3 SMA Negeri 2 Aikmel melalui penerapan pembelajaran kooperatif tipe Think Pair Share (TPS).

\section{Metode Penelitian}

Penelitian ini menggunakan metode penelitian tindakan kelas (PTK). Penelitian tindakan kelas adalah penelitian tindakan yang dilakukan oleh guru dengan tujuan untuk memperbaiki mutu pelaksanaan pembelajaran di kelasnya (Suparno, 2008). Selain itu menurut Arikunto (2009), PTK merupakan suatu pencermatan terhadap kegiatan pembelajaran berupa sebuah tindakan, yang sengaja dimunculkan dan terjadi dalam sebuah kelas secara bersamaan. Dengan demikian, PTK berfokus pada proses belajarmengajar yang terjadi di kelas dan dilakukan pada situasi yang sebenarnya (alami). Hal ini berarti bahwa tindakan tersebut merupakan suatu kegiatan yang sengaja dirancang untuk dilakukan oleh siswa dengan tujuan tertentu. Oleh karena tujuan PTK adalah memperbaiki kualitas proses pembelajaran, maka kegiatan yang dilakukan haruslah berupa tindakan yang diyakini lebih baik dari kegiatan-kegiatan yang biasa dilakukan. Dalam penelitian ini, dilakukan dalam beberapa siklus. Setiap setiap siklus terdiri dari empat langkah, yaitu: (1) perencanaan, (2) pelaksanaan, (3) pengamatan/observasi, dan (4) refleksi.

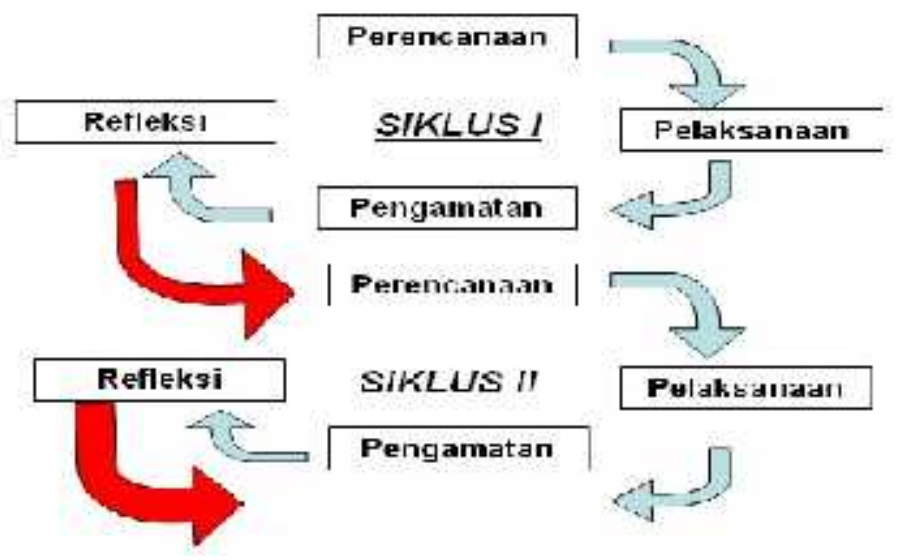

\section{Gambar 1. Desain Penelitian Tindakan Kelas}

Subjek penelitian ini adalah siswa kelas XII IPS SMA Negeri 2 Aikmel sebanyak 27 siswa di mana siswa laki-laki berjumlah 18 orang dan perempuan berjumlah 9 orang. Penelitian ini juga melibatkan guru mata pelajaran akuntansi sebagai kolaborator. Teknik pengumpulan data meliputi observasi, tes, dokumentasi, dan wawancara. Sedangkan teknik analisis datanya menggunakan analisis deskriptif kualitatif dan kuantitatif.

\section{Hasil Penelitian dan Pembahasan}

Dalam penelitian PTK ini dilaksanakan dalam dua siklus dimana setiap siklus terdiri dari empat tahap, yaitu: (1) perencanaan tindakan, (2) pelaksanaan tindakan, (3) observasi 
tindakan, dan (4) refleksi tindakan. Berdasarkan hasil penelitian yang telah dilakukan dapat disimpulkan bahwa pembelajaran koooperatif tipe TPS dapat meningkatkan hasil belajar akuntasi siswa XII IPS 3 SMA Negeri 2 Aikmel. Secara lengkap mengenai hasil penelitian pelaksanakan PTK yang telah dilaksanakan dapat dipaparkan sebagai berikut.

Observasi awal adalah langkah pertama yang dilakukan untuk mengetahui masalah pembelajaran yang muncul di kelas XII IPS 3 SMA Negeri 2 Aikmel. Hasil observasi awal menunjukkan bahwa hasil belajar akuntansi perlu ditingkatkan. Peneliti bersama kolaborator berdiskusi dan menerapkan pembelajaran kooperatif tipe TPS (Think Pair Share) untuk meningkatkan hasil belajar akuntansi.

Selanjutnya, peneliti bersama kolaborator menyusun RPP dan skenario pembelajaran yang kemudian dilaksanakan pada siklus pertama dengan materi pembelajaran Laporan Laba/Rugi dan Laporan Perubahan Modal. Guru selaku pengajar memberikan penjelasan tentang prosedur pembelajaran TPS dan mulai membagi 36 siswa ke dalam kelompokkelompok kecil, di mana satu kelompok terdiri dari empat siswa (dua pasangan). Setelah guru selesai mempresentasikan materi pembelajaran dalam media power point, siswa diskusi berpasangan untuk menyelesaikan soal kelompok yang diberikan oleh guru.

Pertemuan berikutnya diisi dengan melanjutkan diskusi berkelompok menyelesaikan soal diskusi. Pertemuan ketiga diisi dengan presentasi siwa. Guru menentukan kelompok yang akan mempresentasikan hasil kerja kelompok dan guru bertugas untuk memfasilitasi jalannya diskusi. Pada pertemuan ini terlihat siswa belum terbisa melakukan presentasi dan dalam proses diskusi kelas masih ada siswa yang pasif. Pertemuan keempat siklus pertama diakhiri dengan tes individu. Hasil belajar siswa selama siklus I dapat dilihat dari tabel di bawah ini.

Tabel 1. Hasil Belajar Siswa Siklus I

\begin{tabular}{|l|c|c|}
\hline \multicolumn{2}{|c|}{ SIKLUS 1 } \\
\hline \multicolumn{1}{|c|}{ Aspek yang Dinilai } & Jumlah & \% \\
\hline Keaktifan siswa selama apersepsi & 13 & 59 \\
\hline Keaktifan selama pembelajaran & 15 & 68 \\
\hline Keaktifan siswa selama diskusi & 14 & 63 \\
\hline Ketuntasan hasil belajar (KKM 65) & 17 & 77 \\
\hline
\end{tabular}

Tabel di atas menunjukkan bahwa keaktifan siswa dan hasil belajar siswa belum mencapai indikator yang telah ditetapkan peneliti. Adapun penyebabnya antara lain siswa yang merasa kurang cocok dengan teman satu kelompok sehingga tidak mau bekerja sama dan memilih mengerjakan soal secara individu, siswa belum berani menyampaikan pendapat saat kelompok lain mempresentasikan hasil kerja mereka sehingga partisipasi siswa dalam diskusi masih kurang, siswa pun masih terlihat suka tidak berkonsentrasi saat mengikuti pembelajaran, selain itu ada beberapa siswa yang tidak selesai mengerjakan tes karena belum memahami materi. Kelemahan-kelemahan yang ada disiklus pertama perlu diperbaiki maka peneliti bersama kolaborator menyusun skenario pembelajaran dan RPP untuk siklus kedua. Siklus kedua berlangsung sebanyak empat kali pertemuan dengan materi pembelajaran Laporan Neraca. Pada siklus kedua ini guru memperbaiki pembelajaran dengan melakukan pendekatan kepada siswa yang acuh tak acuh terhadap pembelajaran dan tidak dapat bekerja sama dengan kelompok/ pasangannya. Pendekatan tersebut membuat siswa menjadi lebih termotivasi dalam mengikuti pembelajaran. Pembelajaran di siklus kedua ini berlangsung lebih interaktif daripada siklus-siklus sebelumnya. Siswa sudah mulai terbiasa dengan pembelajaran kooperatif tipe TPS dan masing-masing anggota kelompok juga sudah mampu 
berkomunikasi dengan baik antaranggota kelompok. Walaupun masih ada beberapa siswa yang belum berani mengungkapkan pendapat jika belum dimotivasi oleh guru, tetapi secara umum pembelajaran kooperatif tipe TPS pada siklus kedua ini sudah berjalan dengan baik dan lancar. Hasil belajar siswa selama siklus II dapat dilihat dari tabel di bawah ini.

Tabel 2. Hasil Belajar Siswa Siklus 2

\begin{tabular}{|l|c|c|}
\hline \multicolumn{2}{|c|}{ SIKLUS 1 } \\
\hline \multicolumn{1}{|c|}{ Aspek yang Dinilai } & Jumlah & \% \\
\hline Keaktifan siswa selama apersepsi & 16 & 72 \\
\hline Keaktifan selama pembelajaran & 18 & 81 \\
\hline Keaktifan siswa selama diskusi & 20 & 90 \\
\hline Ketuntasan hasil belajar (KKM 65) & 20 & 90 \\
\hline
\end{tabular}

Berdasarkan tabel diatas, diketahui bahwa keaktifan siswa dan hasil belajar siswa melebihi indikator yang telah ditetapkan peneliti. Hal itu menunjukkan dalam pelaksanaan siklus 2 ada peningkatan yang baik. Adapun peningkatan tersebut dikarenakan ada perlakuan yang sedikit berbeda dengan siklus pertama untuk tujuan perbaikan. Pada saat menjelaskan materi guru berupaya berinteraksi dengan siswa dalam bentuk memerikan pertanyaan-pertanyaan untuk memancing supaya siswa terfokus pada pelajaran disamping itu guru terus memotivasi siswa pada saat mereka menyelesaikan soal diskusi ataupun presentasi baik dalam bentuk ucapan atau mimik muka. Tidak lupa juga guru terus mengingatkan siswa supaya memastikan tiap anggota kelompok sudah paham materi. Hasil penelitian dari siklus pertama dan siklus kedua dapat diperbandingkan untuk mengetahui perubahan yang terjadi. Berikut tabel dan grafik perbandingan kedua siklus tersebut.

Tabel 3. Hasil Belajar Siswa Selama Pembelajaran Kooperatif Tipe TPS

\begin{tabular}{|l|c|c|c|}
\hline \multicolumn{1}{|c|}{ Aspek yang Dinilai } & $\begin{array}{c}\text { Siklus } \\
\text { Pertama/ } \\
\text { Jumlah } \\
(\boldsymbol{\%})\end{array}$ & $\begin{array}{c}\text { Siklus } \\
\text { Kedua/ } \\
\text { Jumlah } \\
(\boldsymbol{\%})\end{array}$ & Peningkatan \\
\hline Keaktifan siswa selama apersepsi & $13 / 59$ & $16 / 79$ & $20 \%$ \\
\hline Keaktifan selama pembelajaran & $15 / 68$ & $18 / 81$ & $13 \%$ \\
\hline Keaktifan siswa selama diskusi & $14 / 63$ & $20 / 90$ & $27 \%$ \\
\hline Ketuntasan hasil belajar (KKM 65) & $17 / 77$ & $20 / 90$ & $13 \%$ \\
\hline
\end{tabular}

Tabel di atas adalah hasil PTK dengan penerapan pembelajaran kooperatif tipe TPS dilihat dari keaktifan siswa selama pembelajaran dan hasil belajar kognitif siswa. Secara umum, keaktifan siswa selama pembelajaran mengalami peningkatan baik dari indikator keaktifan siswa selama apersepsi, keaktifan siswa selama mengikuti pembelajaran, dan keaktifan siswa selama diskusi juga meningkat. Peningkatan tersebut menunjukkan bahwa siswa semakin terbiasa dengan pembelajaran kooperatif tipe TPS. Hal tersebut ditunjukkan dengan presentase siswa yang aktif selama pembelajaran berlangsung mengalami perkembangan yang positif. Siswa menjadi terbiasa berdiskusi dengan pasangan dan kelompok dan juga mulai terbiasa bertanya dan mengungkapkan pendapatnya di depan kelompok lain serta suasana pembelajaran lebih menyenangkan. Hasil belajar siswa dari segi kognitif mengalami peningkatan hal ini dapat dilihat dari persentase jumlah siswa yang tuntas pada siklus ke-1 dan siklus ke-2.

Berdasarkan penelitian yang telah dilaksanakan, maka dapat dikatakan bahwa guru berhasil melaksanakan pembelajaran yang menyenangkan sehingga dapat meningkatkan 
keaktifaan dan hasil belajar siswa dalam mata pelajaran ekonomi/akuntansi. Di samping itu, peneliti juga dapat ikut meningkatkan kinerja guru dalam melaksanakan pembelajaran yang efektif dan menarik. Secara umum dapat disimpulkan bahwa hasil belajar ekonomi/akuntansi siswa di kelas XII IPS 3 SMA Negeri 2 Aikmel mengalami peningkatan.

\section{Kesimpulan}

Kesimpulan yang diperoleh dari hasil penelitian ini adalah penerapan pembelajaran kooperatif tipe TPS dapat meningkatkan hasil belajar ekonomi/akuntansi siswa di kelas XII IPS 3 SMA Negeri 2 Aikmel Tahun Pelajaran 2009/2010 yang didukung oleh fakta-fakta yakni keaktifan siswa dalam apersepsi meningkat sebanyak 20\%, keaktifan siswa dalam mengikuti pembelajaran kooperatif tipe TPS meningkat sebanyak 13\%, keaktifan siswa dalam diskusi berpasangan/ kelompok meningkat sebanyak $27 \%$, ketuntasan hasil belajar meningkat sebesar 13\%, dan keaktifan siswa dalam diskusi mengalami peningkatan terbesar dibandingkan dengan keaktifan dan ketuntasan hasil belajar siswa lainnya. Hal tersebut disebabkan siswa memberi respon yang positif terhadap tugas yang diberikan guru dengan aktif berdiskusi dalam pasangan/ kelompok.

\section{Saran}

Beberapa saran dalam penelitian ini adalah guru diharapkan dapat selalu memberikan motivasi dan semangat pada siswa selama mengikuti pembelajaran akuntansi sehingga siswa lebih percaya diri ketika mengerjakan soal-soal akuntansi dan lebih aktif. Pembelajaran kooperatif tipe TPS dapat dimanfaatkan untuk mengembangkan kemampuan siswa secara sosial seperti: kerja sama, kekompakan, memecahkan masalah, dan saling bertukar pendapat dengan anggota kelompok yang lain dan pembelajaran kooperatif tipe TPS dapat dimanfaatkan pula untuk meningkatkan parsipasi aktif siswa selama pembelajaran. Sekolah hendaknya memberikan dukungan kepada guru dalam bentuk bimbingan dan pembinaan tentang metode pembelajaran inovatif dan efektif agar keberhasilan pembelajaran di dalam kelas dapat tercapai.

\section{Daftar Pustaka}

Arikunto, Suharsimi. (2009). Dasar-Dasar Evaluasi Pendidikan. Jakarta: PT. Bina Aksara Burengge, S. (2020). Penerapan Model Pembelajaran Kooperatif Tipe STAD dengan Pendekatan Kontekstual bagi Siswa SDN 7 Tentena Sulawesi Tengah. Jurnal Paedagogy, 7(4), 275-280. doi:https://doi.org/10.33394/jp.v7i4.2832

Djamarah, S. B. (2008). Strategi belajar Mengajar. Bandung: Rineka Cipta.

Harni, H. (2020). Meningkatkan Kemampuan Membaca Melalui Penerapan Pembelajaran Kooperatif Model Jigsaw pada Siswa Kelas IV SDN 2 Uebone. Jurnal Paedagogy, 7(2), 108-114. doi:https://doi.org/10.33394/jp.v7i2.2503

Haulid, H. (2020). Meningkatkan Hasil Belajar Melalui Pembelajaran Kooperatif Tipe Ngroup To Group Exchange (NTGE) pada Mata Pelajaran Fikih bagi Siswa MTs. AlIkhlas Mentigi. Jurnal Paedagogy, $\quad 7(4), \quad 369-376$. doi:https://doi.org/10.33394/jp.v7i4.2930

Heryati, Yeti dan Muhsin, Mumuh. (2014). Manajemen Sumber Daya Pendidikan. Bandung: CV Pustaka Setia.

Iskandar. (2009). Metodologi Penelitian Kualitatif. Jakarta: Gaung Persada Press. Idi, Abdullah. (2014). Sosiologi Pendidikan. Jakarta: Rajawali Pers.

Lie, Anita. (2005). Cooperatif Learning. Jakarta: Gramedia Widiasarana. 
Nasution, S., (2002). Didaktik Azas Mengajar. Bandung: Bumi Aksara.

Noge, M., Tegu, Y., \& Kaka, P. (2020). Model Pembelajaran Kooperatif Tipe Inside-Outside Circle dalam Pembelajaran Bilingual Terhadap Hasil Belajar Siswa. Jurnal Kependidikan: Jurnal Hasil Penelitian dan Kajian Kepustakaan di Bidang Pendidikan, Pengajaran dan Pembelajaran, 6(3), 451-459. doi:https://doi.org/10.33394/jk.v6i3.2640

Rustaman, N. (2001). Ilmu dan Aplikasi Pendidikan. Bandung: Inperial Bakti Utama.

Sa'idah. (2006). Model Pembelajaran Inovatif Dalam Kurikulum 201.

Suparno, Paul. (2008). Riset Tindakan untuk Pendidikan. Jakarta: PT Gramedia Widia Sarana Indonesia.

Suryani, E. (2018). Meningkatkan Hasil Belajar Ekonomi Melalui Pembelajaran Kooperatif Metode Think Pair Share pada Siswa Kelas XI SMA Negeri 3 Mataram. Jurnal Kependidikan: Jurnal Hasil Penelitian dan Kajian Kepustakaan di Bidang Pendidikan, Pengajaran dan Pembelajaran, 4(2), 141-150. doi:https://doi.org/10.33394/jk.v4i2.1122

Trinova, Zulvia. (2012). Hakikat Belajar dan Bermain Menyenangkan bagi Peserta Didik. Jurnal Al-Ta'lim, Jilid 1, Nomor 3 hlm. 209-215.

Usman, M. Basyiruddin. (2002). Metode Pembelajaran Agama Islam. Jakarta: Ciputat Press.

UU No. 20 Tahun 2003 tentang Sisdiknas. 